\title{
Przeszczepienie allogenicznych krwiotwórczych komórek macierzystych w leczeniu chorych na mielofibrozę
}

\author{
Allogeneic hematopoietic stem cell transplantation \\ for treating patients with myelofibrosis
}

\author{
Elżbieta Patkowska ${ }^{1,2}$, Joanna Góra-Tybor ${ }^{1}$ \\ ${ }^{1}$ Klinika Hematologii, Instytut Hematologii i Transfuzjologii, Warszawa \\ ${ }^{2}$ Klinika Hematologii i Transfuzjologii, Centrum Medyczne Kształcenia Podyplomowego, Warszawa
}

\begin{abstract}
Streszczenie
Spośród nowotworów mieloproliferacyjnych Ph-ujemnych najczestszym wskazaniem do przeszczepienia allogenicznych krwiotwórczych komórek macierzystych (allo-HSCT) jest mielofibroza. Ze wzglęu na duze ryzyko procedury do allo-HSCT kwalifikuje sie pacjentów, u których przewidywany czas przeżycia jest krótszy niz 5 lat, a zatem chorych obciażonych ryzykiem pośrednim-2 $i$ wysokim wedtug IPSS, DIPSS $i$ DIPSS Plus. W ostatnim czasie podkreśla sie potrzebe wyodrębnienia z grupy cechujacej się ryzykiem pośrednim-1 pacjentów o gorszym rokowaniu, u których należatoby rozważyć wskazania do allo-HSCT. Do tej grupy, wedtug zaleceń ELN/EBMT z 2015 roku, należa pacjenci wymagajacy przetoczeń koncentratów krwinek czerwonych, $z$ więcej niż $2 \%$ blastów we krwi obwodowej i/lub niekorzystnym kariotypem. Przy kwalifikacji do przeszczepienia należy także uwzgledniać niekorzystne molekularne czynniki ryzyka, takie jak tak zwana potrójna negatywność (nieobecność mutacji JAK, CALR i MPL) oraz obecność mutacji ASXL1. W ostatnich latach liczba allo-HSCT u chorych na MF istotnie wzrosta w zwiazku z rozpowszechnieniem przeszczepień poprzedzonych kondycjonowaniem o zredukowanej intensywności, a także przeszczepień od dawców alternatywnych (krew pępowinowa, dawcy haploidentyczni). Brakuje prospektywnych, randomizowanych badań, w których porównano by skuteczność procedury w zależności od rodzaju kondycjonowania $i$ doboru dawcy.
\end{abstract}

Słowa kluczowe: mielofibroza, transplantacja, przeszczepienie allogenicznych krwiotwórczych komórek macierzystych (allo-HSCT), kondycjonowanie o zredukowanej intensywności (RIC), kondycjonowanie mieloablacyjne (MAC), ruksolitynib

Hematologia 2017; 8, 2: 132-143

\begin{abstract}
Within Ph-negative myeloproliferative types of cancer, myelofibrosis is the most frequent indication for performing allogeneic hematopoietic stem cell transplantation (allo-HSCT). Because this is a high-risk procedure, only those patients with a predicted overall survival below 5 years become eligible, as well as those of intermediate-2 or high disease risk; as defined by the IPSS, DIPSS and DIPSS Plus prognostic indices. It has however recently been recognised that patients with a poor prognosis, who belong to the intermediate-1 disease risk group, need to be distinguished and also
\end{abstract}

Adres do korespondencji: Elżbieta Patkowska, Klinika Hematologii, Instytut Hematologii i Transfuzjologii, 02-776 Warszawa, ul. Indiry Gandhi 14, tel. 223496 322, faks 223496 335, e-mail: epatkowska@ihit.waw.pl 
considered for allo-HSCT. According to ELN/EBMT recommendations from 2015, this group should include patients requiring red blood cell concentrate transfusions who have more than $2 \%$ blasts in the circulation and/or an adverse karyotype. When qualifying patients for transplantation, consideration should also be given to adverse molecular risk factors such as the so-called triple negativity (absence of JAK, CALR and MPL mutations) and the presence of ASXL1 mutation. Over recent years, the number of allo-HSCT performed on patients with MF has significantly risen because the number of transplantations using reduced-intensity conditioning regimens has increased, together with those from unrelated donors (cord blood, haploidentical donors). There is a lack of randomised studies comparing the effectiveness of this transplantation procedure according to the types of conditioning and donor selection.

Key words: myelofibrosis, transplantation, allogeneic hematopoietic stem cell transplantation (allo-HSCT), transplantation, reduced-intensity conditioning (RIC), myeloablative conditioning (MAC), ruxolitinib

Hematologia 2017; 8, 2: 132-143

\section{Wprowadzenie}

Mielofibroza (MF, myelofibrosis) należy do nowotworów mieloproliferacyjnych (MPN, myeloproliferative neoplasm) BCR-ABL1-ujemnych. Może się rozwijać de novo jako pierwotna mielofibroza (PMF, primary myelofibrosis) lub wtórnie jako progresja czerwienicy prawdziwej (post-PV MF, post-policythemia vera myelofibrosis) lub nadpłytkowości samoistnej (post-ET MF, post-essential thrombocythemia) [1]. Charakteryzuje się klonalną proliferacją komórek mieloidalnych prowadzącą do zwiększonego uwalniania cytokin, reaktywnego włóknienia szpiku $z$ osteosklerozą, hematopoezy pozaszpikowej. Zapadalność na PMF wynosi od 0,5 do 1,5/100 000 mieszkańców/rok. W porównaniu $\mathrm{z}$ innymi MPN BCR-ABL1-ujemnymi - ET i PV - w MF obserwuje się wyższe ryzyko transformacji do ostrej białaczki szpikowej (AML, acute myeloid leukemia) oraz krótsze okresy przeżycia (OS, overall survival) [2-5]. Szacowany średni OS pacjentów z MF wynosi 6-7 lat; w populacji chorych obserwuje się zróżnicowane przeżycia od kilku miesięcy do wielu lat $[2,5,6]$. W grupie MPN chorobą o najcięższym przebiegu jest MF, dlatego przeszczepienie allogenicznych krwiotwórczych komórek macierzystych (allo-HSCT, allogeneic hematopoietic stem cell transplantation) ma usankcjonowaną pozycję $\mathrm{w}$ jej leczeniu. Jednakże, $z$ powodu wysokiej śmiertelności okołoprzeszczepowej, allo-HSCT jest zarezerwowane dla pacjentów w zaawansowanych fazach choroby, $z$ medianą czasu przeżycia poniżej 5 lat, czyli z grup pośredniego-2 i wysokiego ryzyka według skal prognostycznych IPSS (International Prognostic Scoring System), DIPSS (Dynamic IPSS),
DIPSS Plus [1]. Mediana wieku w momencie rozpoznania MF wynosi 65 lat. Dlatego wprowadzenie do leczenia schematów $z$ kondycjonowaniem o zredukowanej intensywności (RIC, reduced-intensity conditioning) umożliwiło szersze zastosowanie allo-HSCT w populacji osób starszych, bardziej obciążonych chorobami współistniejącymi. Jednocześnie po dokonaniu optymalizacji postępowania zapobiegającego nawrotom MF po allo-HSCT, $\mathrm{w}$ tym wprowadzeniu ścisłego monitorowania molekularnego minimalnej choroby resztkowej (MRD, minimal residual disease) oraz infuzji limfocytów dawcy (DLI, donor lymphocyte infusion), uzyskano poprawę wyników leczenia. Ograniczenia w zastosowaniu allo-HSCT stanowią takie czynniki, jak wysokie ryzyko hepatotoksyczności oraz niewydolności przeszczepu (GF, graft failure), wynikające $z$ obecności nadciśnienia wrotnego, masywnej splenomegalii czy włóknienia szpiku [1]. Nadal brakuje prospektywnych, randomizowanych badań, w ramach których porównano by allo-HSCT $z$ leczeniem farmakologicznym, w tym inhibitorami JAK1/2, jak również badań służących porównaniu kondycjonowania mieloablacyjnego (MAC, myeloablative conditioning) z RIC $\mathrm{w}$ tym wskazaniu [5].

\section{Kwalifikacja do allo-HSCT}

Skale prognostyczne IPSS,

\section{DIPSS, DIPSS Plus}

Mielofibroza jest chorobą o heterogennym przebiegu, a prawdopodobieństwo OS różni się istotnie zależnie od zaawansowania choroby. Bardzo ważne dla rokowania i właściwego leczenia pacjentów jest zakwalifikowanie do odpowiedniej grupy ryzyka. Powszechnie stosowanymi skalami 
prognostycznymi są IPSS oraz DIPSS, która uwzględnia te same parametry, jednak nie tylko $\mathrm{w}$ chwili rozpoznania, ale także w przebiegu choroby [7-9]. Nowszą modyfikacją jest wskaźnik DIPSS Plus, uwzględniający dodatkowo: zależność od przetoczeń koncentratów krwinek czerwonych (kkcz), zmniejszoną liczbę płytek (PLT, platelets) oraz niekorzystny kariotyp (tj. kariotyp złożony, $+8,-7 /-7 \mathrm{q}$, i (17p), -5/-5q, 12p-, inv (3), rearanżacje 11q23) [9]. Pacjenci są kwalifikowani do czterech grup ryzyka — niskiego, pośredniego-1, pośredniego-2 oraz wysokiego, różniących się istotnie pod względem OS. Strategia leczenia MF zależy od stopnia zaawansowania choroby, tak zwana risk-adapted therapy.

Ze względu na duże ryzyko procedury (śmiertelność okołoprzeszczepowa sięgająca 40\%) do allo-HSCT kwalifikuje się pacjentów, u których przewidywane OS jest krótsze niż 5 lat, a zatem chorych obciążonych ryzykiem pośrednim-2 i wysokim według IPSS i DIPSS [7-11]. Kröger i wsp. [12] przeprowadzili retrospektywną analizę obejmującą 438 chorych na MF, w ramach której porównali OS pacjentów poddanych allo-HSCT i otrzymujących konwencjonalną terapię. Względne ryzyko zgonu $\mathrm{u}$ chorych poddanych allo-HSCT w porównaniu $z$ terapią farmakologiczną wynosiło 5,6 (95-proc. przedział ufności [CI, confidence interval]; 1,7-19; $\mathrm{p}=0,0051)$ u pacjentów $\mathrm{z}$ grupy niskiego ryzyka; $1,6(95 \% \mathrm{CI} ; 0,79-3,2 ; \mathrm{p}=0,19) \mathrm{w}$ przypadku ryzyka pośredniego-1, 0,55 (95\% CI; $0,36-0,83$; $\mathrm{p}=0,005) \mathrm{w}$ przypadku ryzyka pośredniego- 2 i 0,37 (95\% CI; $0,21-0,66 ; p=0,0007)$ w odniesieniu do wysokiego. $\mathrm{W}$ analizie potwierdzono zatem korzyść odnoszoną przez pacjentów poddanych allo-HSCT $z$ grup ryzyka pośredniego-2 i wysokiego. Natomiast pacjenci $z$ grupy ryzyka pośredniego-1 wymagają szczególnie wnikliwej oceny i uwzględnienia dodatkowych czynników ryzyka. Przeprowadzoną analizą objęto pacjentów poniżej 65. roku życia, nieleczonych ruksolitynibem.

Należy podkreślić, że brakuje randomizowanych badań, w których porównano by skuteczność terapii farmakologicznej $z$ allo-HSCT.

Na podstawie przeglądu publikacji w MEDLINE, EMBASE i PubMed (w okresie od 1999 do 31 stycznia 2015 r.) oraz doniesień zjazdowych (ASH [American Society of Hematology], EHA [European Hematology Association], ASCO [American Society Of Clinical Oncology]) przez ekspertów ELN (European LeukemiaNet) w porozumieniu $z$ ekspertami EBMT (European Society of Blood and Bone Marrow Transplantation) dokonano analizy prac, w których oceniano wyniki allo-HSCT zarówno w PMF, jak i post-PV MF oraz post-ET MF. Wnioski opublikowano w 2015 roku jako zalecenia ELN/ /EBMT. Jako kandydaci do allo-HSCT powinni być rozważani wszyscy pacjenci obciążeni ryzykiem pośrednim-2 i wysokim według IPSS, DIPSS lub DIPSS+ w wieku poniżej 70 lat [5].

\section{Markery molekularne}

Odkrycie mutacji V617F eksonu 14 genu kinazy tyrozynowej JAK2 w 2005 roku, stwierdzanej u około 50\% pacjentów $z$ MF, było początkiem poznania molekularnej patogenezy tej choroby [13]. Następnie zidentyfikowano mutację W515L/K w obrębie genu receptora dla trombopoetyny (MPL, myeloproliferative leukemia virus oncogene), która występuje u 5-10\% chorych [14]. W 2013 roku dwie niezależne grupy badawcze opisały mutacje somatyczne nowego onkogenu CALR (calreticulin), kodującego białko (kalretikulinę), występujące u około $80 \%$ pacjentów z PMF niebędących nosicielami mutacji JAK2 ani MPL [15-17]. Analiza przebiegu $\mathrm{MF}$ u pacjentów $\mathrm{z}$ obecnością mutacji $C A L R$ wykazała, że w porównaniu $z$ chorymi $J A K(+)$ i $M P L(+)$ charakteryzują się oni niższą leukocytozą, większą liczbą PLT, a ponadto istotnie dłuższe jest $u$ nich OS. W przypadku MF szczególnie źle rokują pacjenci tak zwani potrójnie negatywni $-\mathrm{z}$ nieobecnością mutacji JAK, CALR i MPL. Istotnie skrócone jest u nich OS, a ryzyko transformacji blastycznej pozostaje zwiększone $[18,19]$.

Poza omówionymi zmianami genetycznymi w patogenezie PMF istotną rolę odgrywają mutacje genów zaangażowanych w mechanizmy epigenetyczne. Należą do nich mutacje genów biorących udział w procesach potranslacyjnej modyfikacji histonów (ASXL1, częstość 10-35\%; EZH2, częstość 7-10\%), metylacji DNA (TET2, DNMT3A, $I D H 1 / 2)$, splicingu mRNA (SRFS2, SRF3B1) oraz procesach naprawy DNA (TP53) [20, 21]. Vannucchi i wsp. [20] ocenili wpływ mutacji $A S X L 1$, SRSF2, EZH2, TET2, DNMT3A, CBL, IDH1, IDH2, MPL i JAK2 na przeżycie 898 pacjentów z PMF. Spośród badanych mutacji ASXL1, SRSF2 i $E Z H 2$ wpływały negatywnie na OS, przy czym obecność mutacji $A S X L 1$ wykazywała wpływ niezależny od ryzyka według IPSS i DIPSS. Ponadto pacjentów z obecnością mutacji IDH1/2, SRSF2 i $A S X L 1$ cechowało zwiększone ryzyko transformacji blastycznej. Guglielmelli i wsp. [21] stwierdzili, że obecność przynajmniej jednej mutacji spośród ASXL1, EZH2, SRSF2 i IDH1/2, czyli tak zwane wysokie ryzyko molekularne (HMR, high-molecular risk), wiąże się z krótszym OS i wyższym ryzkiem transformacji blastycznej. Największy odsetek cho- 
rych HMR był wśród pacjentów $z$ wysokim IPSS $(57,3 \%)$, ale również $\mathrm{w}$ grupie niskiego ryzyka według IPSS - u $21,1 \%$ chorych występowała co najmniej jedna $z$ wymienionych mutacji, co istotnie pogarszało ich rokowanie [21]. Tefferi i wsp. [19] opracowali model prognostyczny oparty na obecności mutacji CALR (korzystne rokowanie) i ASXL1 (niekorzystny czynnik prognostyczny), który okazał się niezależny od ryzyka według DIPSS Plus $(p<0,0001)$ i szczególnie przydatny w identyfikacji źle rokujących pacjentów $z$ grup ryzyka niskiego i pośredniego-1. Analiza wielowariancyjna wykazała, że obecność mutacji $A S X L 1$, w przypadku braku mutacji $C A L R$, jest najistotniejszym niekorzystnym czynnikiem ryzyka $\mathrm{w}$ odniesieniu do OS. W całej badanej populacji pacjentów autorzy wyróżnili trzy grupy ryzyka molekularnego: niskie - CALR(+) ASXL1(-) z medianą OS 10,4 roku; pośrednie, obejmujące zarówno pacjentów $C A L R(+) A S X L 1(+)$, jak i $C A L R(-) A S X L 1(-)-z$ medianą OS 5,8 roku, oraz wysokie $C A L R(-) A S X L 1(+)-z$ medianą OS $2,3$ roku ( $\mathrm{p}<0,0001)$. Wśród chorych należących do grup ryzyka niskiego i pośredniego-1 według DIPSS mediana OS wynosiła odpowiednio 20, 9 i 4 lata u pacjentów $z$ grup ryzyka molekularnego niskiego, pośredniego i wysokiego ( $\mathrm{p}<0,0005)$.

Zgodnie $z$ zaleceniami ELN/EBMT obecność ASXL1 oraz PMF tak zwana potrójnie negatywna (nieobecność mutacji JAK V617F, CALR, MPL) u chorych cechujących się ryzykiem pośrednim-1 powinna być rozważona jako wskazanie do allo-HSCT [5, 19, 22]. Należy ponadto podkreślić, że w przypadku chorych należących do grupy ryzyka pośredniego-1 szczególnie źle rokują pacjenci $C A L R(-) A S X L 1(+)$, a zatem powinni być oni rozważani jako kandydaci do allo-HSCT.

\section{Inne czynniki}

Zgodnie $z$ zaleceniami ELN/EBMT pacjenci cechujący się ryzykiem pośrednim-1, w wieku poniżej 65 lat, powinni być rozważani jako kandydaci do allo-HSCT w przypadku niedokrwistości zależnej od transfuzji, małopłytkowości (liczba PLT < 50 G/l), obecności ponad $2 \%$ blastów we krwi obwodowej lub niekorzystnej cytogenetyki [5, 23-25].

\section{Wskaźniki prognostyczne wyników leczenia MF w przypadku wykorzystania allo-HSCT}

Ze względu na małą liczebność badanych grup i retrospektywny charakter analiz wciąż brakuje systemu prognostycznego do oceny prawdopodobieństwa przeżycia pacjentów $z$ MF poddanych
allo-HSCT [1]. W piśmiennictwie są sprzeczne doniesienia odnośnie do wpływu rodzaju dawcy (spokrewniony $v$. niespokrewniony), stopnia zgodności w zakresie ludzkich antygenów leukocytarnych (HLA, human leucocyte antigen) (w pełni zgodny dawca $v$. nie w pełni zgodny dawca), statusu mutacji JAK2 oraz wieku chorego na przeżycie po allo-HSCT [5, 8, 10, 26-30].

W pracy Bacigalupo i wsp. [26] przeanalizowano 46 pacjentów, ze średnią wieku 51 lat, z PMF, poddanych RIC allo-HSCT $z$ kondycjonowaniem opartym na tiotepie. Jako czynniki niekorzystnie wpływające na OS zidentyfikowano przetoczenie powyżej 20 jednostek kkcz przed transplantacją, splenomegalię (długość śledziony $>22 \mathrm{~cm} \mathrm{w}$ badaniu ultrasonograficznym) oraz alternatywnego dawcę definiowanego jako nie w pełni zgodnego w zakresie HLA [26]. W całej badanej grupie prawdopodobieństwo 5-letniego OS wynosiło 45\%, w tym $77 \%$ u pacjentów cechujących się niskim ryzykiem (0-1 niekorzystnych czynników) oraz zaledwie $8 \%(\mathrm{p}=0,001) \mathrm{u}$ pacjentów obciążonych wysokim ryzykiem (2-3 czynniki niekorzystne). Skrócenie OS było spowodowane wyższą śmiertelnością związaną zarówno $z$ przeszczepieniem (TRM, treatment-related mortality) (ryzyko względne $[R R$, relative risk $] 6,0 ; p=0,006)$, jak i wznową choroby (RR 7,69; $\mathrm{p}=0,001)$.

Alchalby i wsp. [8] opracowali skalę prognostyczną dla OS chorych na MF po allo-HSCT na podstawie oceny 150 pacjentów leczonych RIC allo-HSCT. Analiza wielowariancyjna wykazała, że czynnikami niekorzystnie wpływającymi na OS były brak mutacji JAK2 V617F, wiek powyżej 57 lat i obecność objawów ogólnych (współczynnik ryzyka [HR, hazard ratio] odpowiednio 2,02, 2,43 i 2,80) [8]. Zależnie od obecności jednego, dwóch lub trzech czynników ryzyko zgonu wynosiło, odpowiednio, 3,08, 4,70 i 16,61 ( $<<0,001)$.

Wong i wsp. [27] wykazali, że wystąpienie objawów hepatotoksyczności w okresie okołoprzeszczepowym wiąże się ze skróceniem OS $(\mathrm{p}=0,02)$. Autorzy ci zidentyfikowali obecność nadciśnienia wrotnego, zakrzepicę żyły wrotnej $\mathrm{w}$ wywiadzie i przeładowanie żelazem stwierdzone na podstawie biopsji wątroby jako czynniki zwiększające ryzyko uszkodzenia wątroby i względne ryzyko zgonu [27].

Historycznie gorsze wyniki allo-HSCT w MF wiązały się z zaawansowanym wiekiem chorych [28]. Jednakże w opublikowanych w ostatnich latach analizach nie potwierdzono niekorzystnego wpływu starszego wieku na OS, przeżycie wolne od progresji choroby (PFS, progression-free survival) 
ani przeżycie wolne od objawów choroby (DFS, disease-free survival) $[10,30]$. Zgodnie $z$ aktualnymi zaleceniami EBMT/ELN pacjenci $z$ MF $w$ stadium zaawansowania pośrednim-2 lub wysokim powinni być rozważani jako kandydaci do allo-HSCT do 70. roku życia [5]. Niejasna pozostaje przydatność indeksu chorób współistniejących HCT-CI $(\mathrm{He}$ matopoietic Cell Transplantation - Comorbidity Index) do oceny prawdopodobieństwa śmiertelności niezwiązanej $z$ nawrotem (NRM, non-relapse mortality) i OS [29, 30]. W grupie 243 pacjentów $z$ nowotworami hematologicznymi (166 chorych poddanych MAC, 77 chorych poddanych RIC), w tym 6 chorych na MF poddanych allo-HSCT, nie wykazano różnic w zakresie NRM i OS zależnie od wartości HCT-CI [30].

\section{Postępowanie przed allo-HSCT}

\section{Rola inhibitora kinazy JAK1/2}

— ruksolitynibu

Inhibitor kinazy JAK1/2 - ruksolitynib znajduje zastosowanie $\mathrm{w}$ terapii przygotowującej chorych na MF do allo-HSCT. Lek ten wpływa na zmniejszenie rozmiarów śledziony, objawów ogólnych, w tym świądu skóry, potów nocnych, ograniczenie utraty masy ciała oraz przyczynia się do poprawy jakości życia [31]. Redukcja rozmiarów śledziony może obniżyć ryzyko GF. Poprzez zmniejszenie stężenia cytokin prozapalnych i nasilenia objawów ogólnych, poprawę stanu ogólnego przed allo-HSCT oraz obniżenie ryzyka ciężkich postaci choroby przeszczep przeciwko gospodarzowi (GvHD, graft versusu host disease) inhibitory JAK1/2 wpływają na obniżenie ryzyka TRM i poprawę wyników allo-HSCT [32, 34]. Jednakże, rozważając zastosowanie inhibitorów JAK1/2, należy wziąć pod uwagę ich potencjalne działania niepożądane, $w$ tym cytopenie, objawy związane $z$ odstawieniem oraz zwiększone ryzyko infekcji oportunistycznych [31].

Jaekel i wsp. [35] zastosowali ruksolitynib u 14 pacjentów $z$ MF przed allo-HSCT. Mediana czasu terapii wynosiła 6,5 miesiąca. U $70 \%$ chorych obserwowano osłabienie nasilenia objawów ogólnych, u $60 \%$ natomiast zmniejszenie rozmiarów śledziony. Nie zaobserwowano objawów związanych $\mathrm{z}$ odstawieniem leku; ostra postać GvHD (aGvHD, acute GvHD) wystąpiła u $14 \%$ chorych, u 93\% chorych odnotowano wszczepienie. Po medianie obserwacji wynoszącej 9 miesięcy OS, czas wolny od zdarzeń (EFS, event-free survival) i TRM wynosiły, odpowiednio, 78,6\%, 64\% i 7\%. Stübig i wsp. [36] stosowali ruksolitynib u 22 pacjentów z MF przed allo-HSCT. Badacze nie obserwowali objawów odstawienia leku; u wszystkich chorych doszło do wszczepienia, aGvHD w 3. i 4. stopniu nasilenia według WHO wystąpiła u $24 \%$ chorych, $\mathrm{w}$ tym u 1 pacjenta była przyczyną zgonu. Po roku obserwacji parametry OS i DFS wyniosty, odpowiednio, $81 \%$ i $76 \%$ [36]. W prospektywnym, wieloośrodkowym badaniu II fazy, służącym ocenie zastosowania ruksolitynibu przed allo-HSCT, analizą objęto 22 chorych na MF. Ze względu na przypadki ciężkich powikłań, pod postacią wstrząsu kardiogennego, ciężkich postaci zespołu lizy guza, posocznicy, i zgonów w przebiegu aGvHD czasowo wstrzymano rekrutację do badania [37].

Retrospektywna analiza obejmująca 100 pacjentów z MF, którzy otrzymywali inhibitor kinazy JAK przed allo-HSCT (u 90 pacjentów stosowano ruksolitynib), wykazała korzystny wpływ leku przede wszystkim u chorych, u których obserwowano poprawę kliniczną [38]. Tylko u 8 pacjentów wystąpiły objawy niepożądane związane $z$ odstawieniem leku (u 2 chorych spowodowały odroczenie allo-HSCT). Objawy występowały częściej u pacjentów, u których ruksolitynib odstawiono wcześniej niż 6 dni przed rozpoczęciem kondycjonowania.

Zgodnie z zaleceniami ELN/EBMT zastosowanie inhibitorów JAK1/2 przed allo-HSCT jest wskazane $\mathrm{u}$ chorych $\mathrm{z}$ symptomatyczną splenomegalią i/lub objawami ogólnymi. Leczenie inhibitorami JAK1/2 należy rozpocząć przynajmniej 2 miesiące przed planowaną transplantacją, a dawkę zwiększać do maksymalnej tolerowanej. Następnie dawkę leku należy stopniowo zmniejszać 5-7 dni przed kondycjonowaniem, aż do odstawienia dzień przed tą procedurą [5, 38].

Nierozstrzygniętą kwestią pozostaje decyzja o transplantacji u pacjentów obciążonych ryzykiem pośrednim-2 i wysokim według IPSS/DIPSS, którzy dobrze zareagowali na terapię ruksolitynibem. Nie ma randomizowanych badań, w których porównano by skuteczność terapii farmakologicznej $z$ zastosowaniem inhibitorów kinazy JAK1/2 w porównaniu $z$ allo-HSCT. W retrospektywnej analizie porównano wyniki leczenia chorych na MF $z$ grupy pośredniego-2 i wysokiego ryzyka poddanych allo-HSCT $(\mathrm{n}=49) \mathrm{z}$ rezultatami leczenia farmakologicznego, w tym inhibitorem JAK1/2 $(\mathrm{n}=41)$. Mediana OS była podobna w obu grupach i wynosiła 46 miesięcy u pacjentów po allo-HSCT oraz 42 miesiące $u$ chorych leczonych inhibitorem JAK1/2 (p = 0,30). Prawdopodobieństwo OS po roku wynosiło $69 \%$ i $80 \%$, po 3 latach $63 \%$ i $51 \%$, a po 5 latach $49 \%$ i $36 \%$, odpowiednio, u chorych leczonych allo-HSCT i farmakologicznie [39]. 
Biorąc pod uwagę korzystny wpływ terapii ruksolitynibem na wyniki allo-HSCT u chorych, u których nastąpiła poprawa hematologiczna po ruksolitynibie przed transplantacją, [38] oraz czas trwania odpowiedzi na ruksolitynib obserwowany w badaniach COMFORT, [33] leczenie inhibitorem JAK1/2 powinno być pomostem do allo-HSCT i nie wpływać na odroczenie procedury [38].

\section{Splenektomia}

Znaczna splenomegalia stanowi czynnik ryzyka nawrotu oraz śmiertelności związanej z przeszczepieniem [1]. Udowodniono poprawę wydolności przeszczepu u chorych poddanych splenektomii przed allo-HSCT, natomiast nie wykazano wpływu na OS [40, 41]. Należy podkreślić, że zabieg splenektomii jest obarczony 5-10-procentowym ryzykiem zgonu, a u $25 \%$ pacjentów występują powikłania zakrzepowe, krwotoczne i infekcyjne [42]. Wobec dostępności ruksolitynibu, który u około połowy chorych powoduje zmniejszenie rozmiarów śledziony, zastosowanie inhibitora kinazy JAK1/2 jest bezpieczniejszą opcją terapeutyczną. Nie ma randomizowanych badań, w których oceniono by wpływ splenektomii na OS po allo-HSCT u pacjentów z MF; decyzja o usunięciu śledziony wymaga indywidualnej oceny $[1,5]$.

\section{Unikanie przeładowania żelazem}

W wielu analizach wykazano, że podwyższone stężenie ferrytyny pogarsza wyniki allo-HSCT, zwiększając ryzyko powikłań infekcyjnych, zwłaszcza grzybiczych, oraz wpływa na wzrost częstości ostrej i przewlekłej GvHD (cGvHD, chronic GvHD) [43-46]. Ferrytyna jako białko ostrej fazy jest niespecyficznym markerem przeładowania żelazem i jej stężenie wzrasta w przebiegu infekcji, stanów zapalnych czy w przypadku uszkodzenia tkanek. $Z$ tego względu bardziej precyzyjnym markerem przeładowania tkanek żelazem pozostaje ocena zawartości żelaza w wątrobie (LIC, liver iron content) za pomocą rezonansu magnetycznego [47]. Trottier i wsp. [47] w prospektywnym badaniu obejmującym pacjentów poddanych allo-HSCT nie wykazali wpływu podwyższonego LIC na OS, NRM, częstość wznów, infekcji ani GvHD. Podobne wyniki przedstawiono $\mathrm{w}$ metaanalizie obejmującej cztery badania, w których do oceny przeładowania żelazem wykorzystano wskaźnik LIC [43]. Badania $z$ zastosowaniem leków chelatujących u chorych na MF mają charakter retrospektywny i obejmują niewielkie grupy pacjentów [48]. Podstawową metodą ograniczającą przeładowanie żelazem powinna być odpowiednio wczesna kwali- fikacja do transplantacji pacjentów wymagających przetoczeń kkcz [5].

\section{Procedura allo-HSCT}

\section{Znaczenie typu dawcy}

krwiotwórczych komórek macierzystych i rodzaju kondycjonowania

Interpretacja wyników badań klinicznych obejmujących pacjentów $z$ MF poddanych allo-HSCT jest trudna ze względu na małą liczebność grup, zróżnicowanie stosowanych schematów kondycjonujących, typu dawcy oraz źródła komórek krwiotwórczych.

W jednoośrodkowym retrospektywnym badaniu Schmohla i wsp. [29] oceniono wyniki leczenia 57 chorych na MF za pomocą MAC $(\mathrm{n}=19)$ w porównaniu $z$ RIC $(n=35)$. Odnotowano podobne OS i DFS; OS i DFS po 3 latach wynosiło, odpowiednio, $54 \%$ oraz $53 \%$ w przypadku zastosowania RIC i $63 \%$ oraz $58 \%$ w przypadku zastosowania MAC ( $\mathrm{p}=0,8$ / $/ 0,97)$. Stwierdzono natomiast częstsze występowanie GvHD w 2.-4. stopniu nasilenia po MAC w porównaniu $\mathrm{z}$ RIC, odpowiednio, $26 \%$ versus $0 \%$ $(\mathrm{p}=0,004)$. Skumulowany odsetek nawrotów (CIR, cumulative incidence of relapse) oszacowano na $34 \%$ po RIC w porównaniu $z$ 8\% po MAC $(\mathrm{p}=0,16)$ [29].

Największa retrospektywna analiza CIBMTR (Center for International Blood and Marrow Transplant Research) dotyczyła 289 chorych na MF poddanych allo-HSCT, z których 229 otrzymało MAC, a 60 RIC [10]. Mediana wieku pacjentów wynosiła 47 lat, TRM była istotnie wyższa wśród osób, które otrzymały przeczep od dawcy niespokrewnionego (URD, unrelated donor) $\mathrm{w}$ porównaniu $\mathrm{z}$ pacjentami po przeszczepieniu od zgodnego dawcy rodzinnego (MSD, matched sibling donor) i wynosiła, odpowiednio, $42 \%$ i $22 \%$. Pięcioletnie OS wyniosło $37 \% \mathrm{w}$ odniesieniu do MSD i $30 \% \mathrm{w}$ odniesieniu do URD. Nie stwierdzono różnic w zakresie skuteczności allo-HSCT zależnie od kondycjonowania MAC $\mathrm{w}$ porównaniu $z$ RIC.

$\mathrm{W}$ wieloośrodkowym prospektywnym badaniu EBMT, służącym ocenie RIC allo-HSCT w MF, obserwowano niższe NRM w pierwszym roku obserwacji u pacjentów po allo-HSCT od w pełni zgodnego dawcy w porównaniu $z$ dawcą nie w pełni zgodnym w zakresie HLA; NRM wyniosła odpowiednio $12 \%$ versus $38 \%$. Nie wykazano różnic pod względem NRM dla allo-HSCT od zgodnego w zakresie HLA MSD w porównaniu ze zgodnym w zakresie HLA URD. Odsetki NRM wynosiły odpowiednio $10 \%$ versus $13 \%$ [41]. W prospektywnym badaniu II fazy MPD-RC 101 (Myeloproliferative 
Disorder Research Consortium) OS korelowało z rodzajem dawcy (spokrewniony $v$. niespokrewniony, odpowiednio, $75 \% v$. 32\%; $\mathrm{p}<0,001)$ ), natomiast nie ze stopniem niezgodności w zakresie HLA [11].

W analizach Schmochl i wsp. [29] oraz Murata i wsp. [49] nie obserwowano skrócenia OS u chorych na MF po allo-HSCT od dawców nie w pełni zgodnych w zakresie HLA w porównaniu $z$ dawcami w pełni zgodnymi. Analizy nie wykazały również różnic w OS pacjentów, którzy otrzymali HSC od dawców rodzinnych w porównaniu $\mathrm{z}$ niespokrewnionymi $[29,49]$. W pracy Bregante i wsp. [50] wykazano różnice w OS w przypadku MRD w porównaniu $z$ dawca alternatywnym w latach 2000-2010 (45\% v. $21 \% ; \mathrm{p}=0,02)$, natomiast nie stwierdzono różnic w latach 2011-2014 (72\% v. 69\%; p = 0,60). Badacze podkreślają wydłużenie OS u chorych po allo-HSCT w obu grupach dawców w latach 2011-2014; poprawę wyników $\mathrm{w}$ grupie dawców alternatywnych wiążą $z$ wyższym odsetkiem przeszczepień haploidentycznych i z krwi pępowinowej oraz modyfikacją kondycjonowania i profilaktyki GvHD.

Robin i wsp. [51] zaraportowali do Eurocord 35 przeszczepień krwi pępowinowej w MF po kondycjonowaniu napromienianie całego ciała (TBI, total body irradiation)-fludarabina-cyklofosfamid, bez niepowodzeń przeszczepienia. Dwuletnie odsetki OS i EFS wynosity odpowiednio 44\% i 30\% [51]. Trwają badania służące ocenie dawców haploidentycznych w przypadku zastosowania cyklofosfamidu po transplantacji [50].

$\mathrm{W}$ tabeli 1 przedstawiono wyniki wybranych analiz dotyczących leczenia chorych na MF za pomocą allo-HSCT [7-11, 29, 40, 41, 50, 52-57]. Wczesna śmiertelność w pierwszych 100 dniach wynosi 10-30\%. Wysokie wskaźniki NMR, 30$-50 \%$, wynikają z GF, toksyczności terapii, GvHD. Odsetki długoterminowego przeżycia wynoszą 30-70\% [28, 41, 52, 53, 58]. Szczególnie wysoki odsetek nawrotów obserwuje się u chorych $z$ grupy wysokiego ryzyka według klasyfikacji DIPSS. Skumulowane odsetki nawrotów po 3 i 5 latach, raportowane w pracach Schmohla i wsp. [29], Krögera i wsp. [41] oraz Robin i wsp. [40], wynoszą od około $25 \%$ do $30 \%$. Wyższy odsetek nawrotów $\mathrm{w}$ cytowanych pracach dotyczył chorych napost-PV MF w porównaniu $z$ PMF.

Zgodnie $z$ zaleceniami EBMT/ELN w przypadku braku zgodnego w zakresie HLA dawcy spokrewnionego lub niespokrewnionego u chorego na MF kwalifikującego się do allo-HSCT należy poszukiwać dawcy alternatywnego — nie w pełni zgodnego w zakresie HLA, haploidentycznego lub dawcy krwi pępowinowej.

\begin{tabular}{|c|c|c|c|c|c|c|c|}
\hline 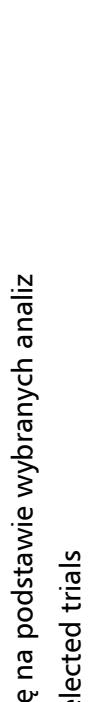 & 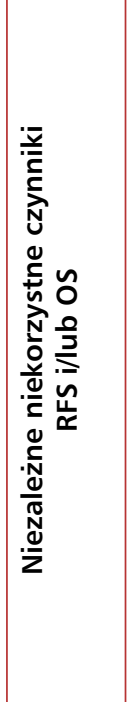 & 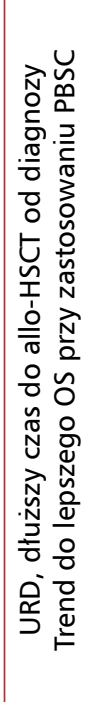 & 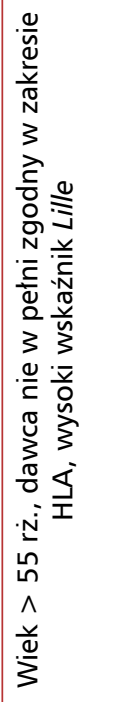 & 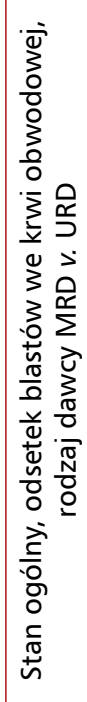 & & 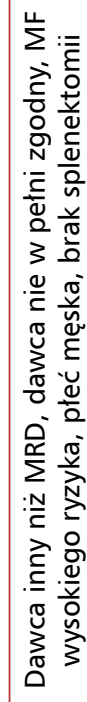 & $\tilde{\underline{\Delta}}$ \\
\hline 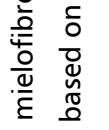 & 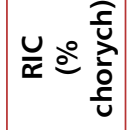 & กิ & $\stackrel{\circ}{-}$ & $\bar{N}$ & & 8 & 1 \\
\hline 을 & 㟧 @ & $\stackrel{\sim}{\simeq}$ & $N$ & $a$ & 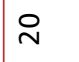 & $\div$ & $\stackrel{L_{n}^{\prime}}{m}$ \\
\hline 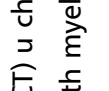 & $\sum_{\text {产 }}$ & भ & 6 它咅 & $\tilde{m}$ & $\stackrel{\infty}{+}$ & 尺ి & $\vec{m}$ \\
\hline 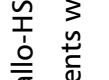 & $\frac{u}{x}$ & $\stackrel{\llcorner}{m}$ & in & $\stackrel{m}{m}$ & $\grave{N}$ & $\tilde{m}$ & in \\
\hline$\stackrel{\pi}{\stackrel{0}{2}}$ & oิ & ษ & 6 & $\frac{\partial}{\Sigma} \hat{m}$ & 举 & $\stackrel{g}{m}$ & กิ \\
\hline 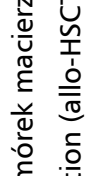 & 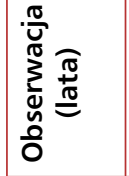 & $m$ & L & in & & ナ & in \\
\hline 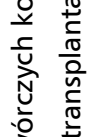 & 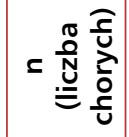 & 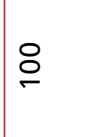 & $\stackrel{m}{\underline{0}}$ & 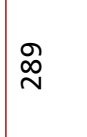 & & 守 & $\stackrel{9}{ }$ \\
\hline 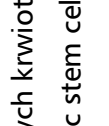 & 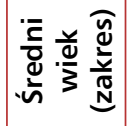 & \& $\frac{\widehat{\infty}}{\underline{0}}$ & 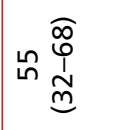 & 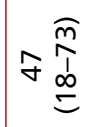 & & م & กำ \\
\hline 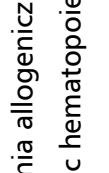 & 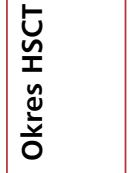 & 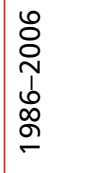 & 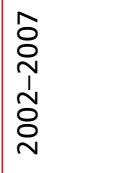 & 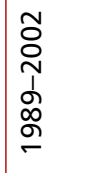 & & 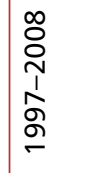 & 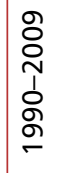 \\
\hline 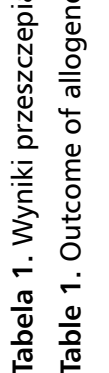 & 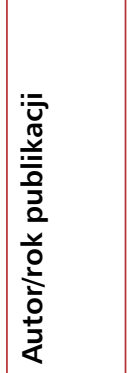 & 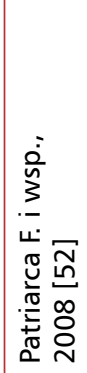 & 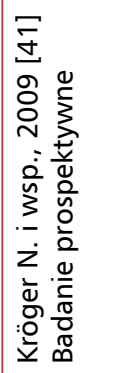 & 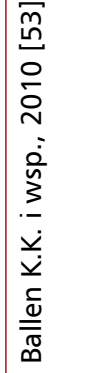 & & 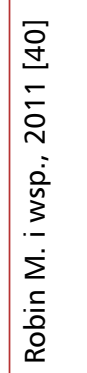 & 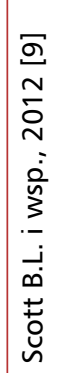 \\
\hline
\end{tabular}




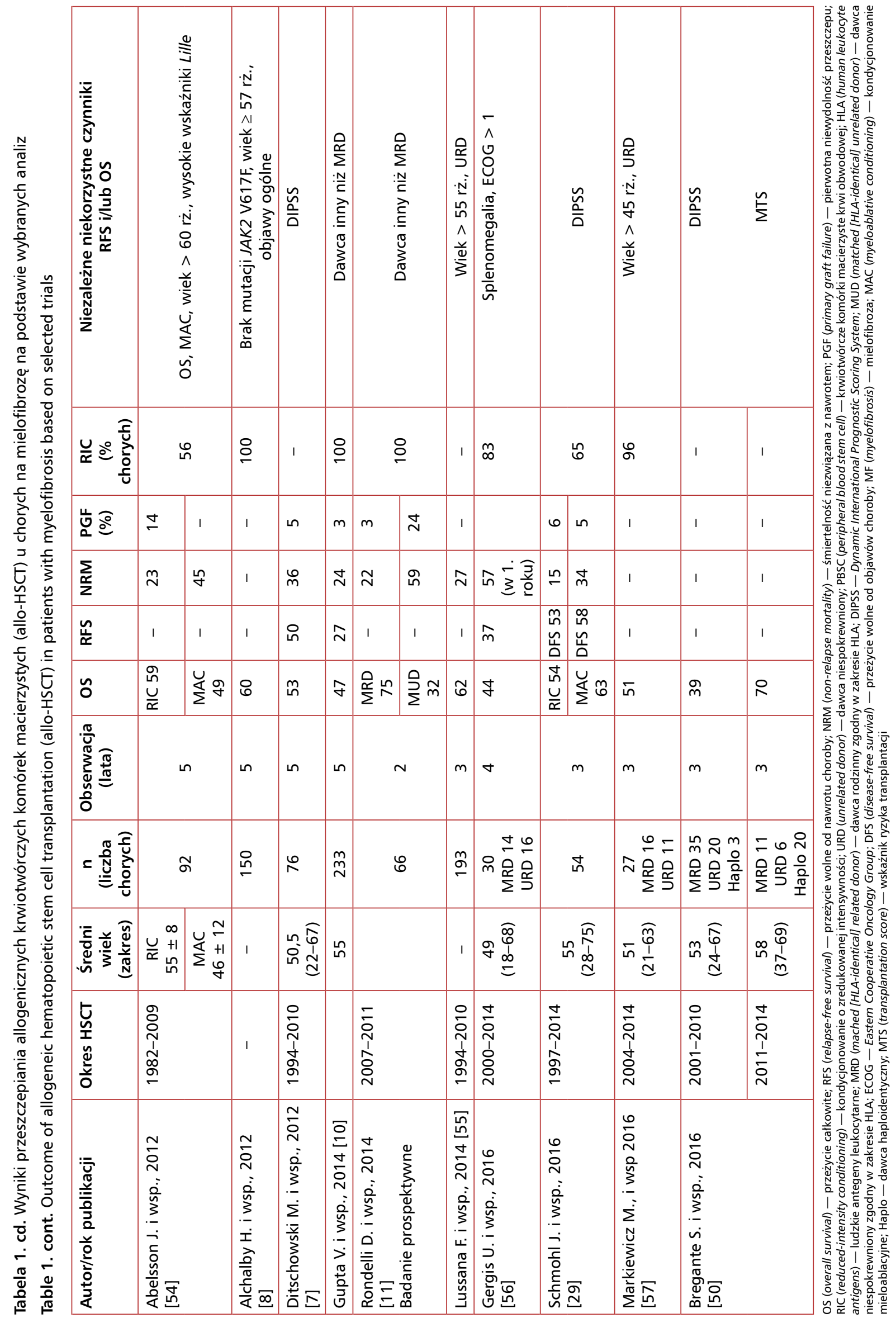




\section{Źródło komórek macierzystych}

W badaniu III fazy, w którym porównywano dwa źródła krwiotwórczych komórek macierzystych (HSC, hematopoietic stem cells) - krew obwodową oraz szpik kostny — od dawców niespokrewnionych, po kondycjonowaniu MAC $\mathrm{w}$ większości przypadków, nie odnotowano różnic w OS, natomiast stwierdzono wyższe ryzyko wystąpienia i większe nasilenie cGvHD w przypadku zastosowania krwi obwodowej [59]. W pracy Schmohl i wsp. [29] nie wykazano istotnych różnic pod względem przeżycia w zależności od źródła HSC. Zgodnie $z$ zaleceniami EBMT/ELN jako najbardziej odpowiednie źródło HSC w pierwszej kolejności powinna być rozważana krew obwodowa [5].

\section{Postępowanie po allo-HSCT}

\section{Niewydolność przeszczepu}

Definicja niewydolności przeszczepu według EBMT/CIBMTR nie jest do końca precyzyjna. W ostatnim czasie do zdefiniowania GF wykorzystuje się następujące kryteria: cytopenia w przynajmniej dwóch liniach hematopoetycznych (liczba neutrofilów $\leq 1,5 \mathrm{G} / 1$, liczba PLT $\leq 30 \mathrm{G} / 1$, stężenie hemoglobiny $\leq 8,5 \mathrm{~g} / \mathrm{dl}$ ) przez co najmniej 2 tygodnie po 14. dobie od udokumentowanego wszczepienia HSC przy pełnym chimeryzmie dawcy, ubogokomórkowym szpiku kostnym przy nieobecności ciężkiej GvHD, infekcji wirusem cytomegalii (CMV, cytomegalovirus), nawrotu choroby podstawowej, mielosupresji polekowej [60,61]. W nowotworach hematologicznych są opisywane następujące czynniki wpływające na wystąpienie GF po allo-HSCT: niezgodność w zakresie HLA między dawcą a biorcą HSC, immunizacja pacjenta wskutek licznych transfuzji preparatów krwi, transplantacje po deplecji limfocytów T, duża niezgodność w zakresie grup ABO przy wykorzystaniu RIC, mała liczba przeszczepionych HSC [62-65]. Patogeneza GF w MPN jest niejasna; jedna $z$ hipotez dotyczy neuropatii włókien wspólczulnych unerwiających mezenchymalne komórki prekursorowe [66].

Pierwotny GF występuje u około $25 \%$ chorych na MF [11, 41], natomiast GF wtórny — przy przetrwałych cytopeniach i malejącycm chimeryzmie u około $10 \%$ chorych. W przypadku splenomegalii $z$ towarzyszącym hipersplenizmem dochodzi do nadmiernego usuwania $z$ krwiobiegu i niszczenia przetoczonych HSC, co może prowadzić do opóźnienia pełnego funkcjonowania HSC. W pracy Alchalby i wsp. [67] powiększenie śledziony wynoszące $10 \mathrm{~cm}$ lub więcej poniżej lewego luku żebrowego przed allo-HSCT skutkowało skumulowaną wyższą częstością GF
(26 v. 13\%; $\mathrm{p}=0$,13). Czynnikami ryzyka GF były: płeć męska, starszy wiek, znaczna splenomegalia przed transplantacją, brak istotnego zmniejszenia rozmiarów śledziony w ciągu 30 dni po transplantacji. Nie wykazano wpływu GF na prawdopodobieństwo 3-letniego przeżycia chorych [67]. Włóknienie podścieliska szpiku kostnego stanowi kolejny problem uniemożliwiający lub opóźniający funkcjonowanie przeszczepionych HSC. Jednakże Alchalby i wsp. [67] odnotowali brak związku upośledzonej funkcji HSC ze stopniem włóknienia oraz stopniem redukcji włóknienia szpiku stwierdzanym w 30 . dniu po allo-HSCT.

\section{Postępowanie w przypadku obecności MRD} lub nawrotu po allo-HSCT

Monitorowanie MRD po allo-HSCT $z$ wykorzystaniem aberracji genetycznych stwierdzanych w kariotypie przy rozpoznaniu oraz markerów molekularnych, w tym mutacji JAK2 V617F, CALR i $M P L$, pozwala na modyfikację postępowania terapeutycznego [5]. Obecność MRD, jak również malejący chimeryzm dawcy, są wskazaniem do stopniowego odstawiania immunosupresji i wykonania DLI. Nawrót MF po allo-HSCT bez uprzedniego ciężkiego GvHD stanowi wskazanie do stopniowego zmniejszania immunosupresji lub zastosowania DLI, a w przypadku braku efektu do rozważenia kolejnego allo-HSCT. U pacjentów, u których nawrotowi towarzyszą splenomegalia i objawy ogólne, jako leczenie eksperymentalne można zastosować inhibitory JAK1/2.

\section{Podsumowanie}

Wybór optymalnego leczenia u chorych na MF stanowi duże wyzwanie. Przeszczepienie allogenicznych krwiotwórczych komórek macierzystych jako jedyna opcja stwarza szanse wyleczenia przy wysokim względnym ryzyku zgonu. Brak prospektywnych, randomizowanych badań, w których porównano by allo-HSCT $z$ leczeniem farmakologicznym, sprawia, że decyzje są podejmowane na podstawie doświadczenia klinicznego. Jednakże poprawa wyników allo-HSCT u chorych na MF w ostatnich latach, w tym redukcja TRM i odsetka nawrotów, oraz poprawa OS, szczególnie w przypadku dawców alternatywnych, w tym haploidentycznych, poprzez modyfikacje kondycjonowania i profilaktyki GvHD umożliwiają coraz szersze stosowanie allotransplantacji.

W 2015 roku wydano zalecenia ELN/EBMT optymalizujące postępowanie u chorych zarówno na PMF, jak i post-PV MF oraz post-ET MF poddawanych allo-HSCT. Autorzy podkreślają 
trudności przy kwalifikacji chorych do procedury transplantacji. Zgodnie $z$ zaleceniami ELN/EBMT rozważenie allo-HSCT jest wskazane u wszystkich pacjentów $z$ MF poniżej 70. roku życia, $z$ grupy ryzyka pośredniego-2 i wysokiego według IPSS/ /DIPSS. Natomiast $\mathrm{u}$ chorych $\mathrm{z}$ grupy ryzyka pośredniego-1, poniżej 65. roku życia, jest zalecane przy opornej na leczenie, zależnej od transfuzji niedokrwistości, w przypadku obecności co najmniej $2 \%$ blastów w rozmazie krwi obwodowej oraz niekorzystnym kariotypie zdefiniowanym w skali DIPSS Plus.

Stosowanie stratyfikacji ryzyka na podstawie markerów molekularnych wymaga dalszych badań. Zaleca się jednak rozważenie allo-HSCT u chorych potrójnie negatywnych (nieobecność mutacji JAK2 V617F, CALR, MPL) i/lub z obecnością mutacji $A S X L 1$. Pacjenci z grupy niskiego ryzyka według IPSS, DIPSS, DIPSS Plus nie powinni być leczeni za pomocą allo-HSCT. Pacjenci z tej grupy wymagają monitorowania i kwalifikacji do allo-HSCT w przypadku progresji choroby.

Przy podejmowaniu decyzji o kwalifikacji do allo-HSCT należy uwzględnić obecność czynników wyższego ryzyka powikłań okołotransplantacyjnych, w tym splenomegalii, przetoczeń powyżej $20 \mathrm{j}$. kkcz, nie w pełni zgodnego w zakresie HLA dawcy HSC, złego stanu ogólnego (ECOG $>2$ ), wysokiego wskaźnika HCT-CI (> 3) oraz nadciśnienia wrotnego.

\section{Piśmiennictwo}

1. Kekre N, Ho VT. Allogeneic hematopoietic stem cell transplantation for myelofibrosis and chronic myelomonocytic leukemia. Am J Hematol. 2016; 91(1): 123-130, doi: 10.1002/ajh.24215, indexed in Pubmed: 26453238.

2. Srour SA, Devesa SS, Morton LM, et al. Incidence and patient survival of myeloproliferative neoplasms and myelodysplastic/ /myeloproliferative neoplasms in the United States, 2001-12. Br J Haematol. 2016; 174(3): 382-396, doi: 10.1111/bjh.14061, indexed in Pubmed: 27061824.

3. Tefferi A, Guglielmelli P, Larson DR, et al. Long-term survival and blast transformation in molecularly annotated essential thrombocythemia, polycythemia vera, and myelofibrosis. Blood. 2014; 124(16): 2507-13; quiz 2615, doi: 10.1182/blood-2014-05-579136, indexed in Pubmed: 25037629.

4. Moulard O, Mehta J, Fryzek J, et al. Epidemiology of myelofibrosis, essential thrombocythemia, and polycythemia vera in the European Union. Eur J Haematol. 2014; 92(4): 289-297, doi: 10.1111/ejh.12256, indexed in Pubmed: 24372927.

5. Kröger NM, Deeg JH, Olavarria E, et al. Indication and management of allogeneic stem cell transplantation in primary myelofibrosis: a consensus process by an EBMT/ELN international working group. Leukemia. 2015; 29(11): 2126-2133, doi: 10.1038/ /leu.2015.233, indexed in Pubmed: 26293647.
6. Tefferi A, Lasho TL, Tischer A, et al. The prognostic advantage of calreticulin mutations in myelofibrosis might be confined to type 1 or type 1-like CALR variants. Blood. 2014; 124(15): 2465-2466, doi: 10.1182/blood-2014-07-588426, indexed in Pubmed: 25301336.

7. Ditschkowski M, Elmaagacli AH, Trenschel R, et al. Dynamic International Prognostic Scoring System scores, pre-transplant therapy and chronic graft-versus-host disease determine outcome after allogeneic hematopoietic stem cell transplantation for myelofibrosis. Haematologica. 2012; 97(10): 1574-1581, doi: 10.3324/ /haematol.2011.061168, indexed in Pubmed: 22491742.

8. Alchalby H, Yunus DR, Zabelina T, et al. Risk models predicting survival after reduced-intensity transplantation for myelofibrosis. Br J Haematol. 2012; 157(1): 75-85, doi: 10.1111/j.13652141.2011.09009.x, indexed in Pubmed: 22280409.

9. Scott BL, Gooley TA, Sorror ML, et al. The Dynamic International Prognostic Scoring System for myelofibrosis predicts outcomes after hematopoietic cell transplantation. Blood. 2012; 119(11): 2657-2664, doi: 10.1182/blood-2011-08-372904, indexed in Pubmed: 22234678.

10. Gupta V, Malone AK, Hari PN, et al. Reduced-intensity hematopoietic cell transplantation for patients with primary myelofibrosis: a cohort analysis from the center for international blood and marrow transplant research. Biol Blood Marrow Transplant. 2014; 20(1): 89-97, doi: 10.1016/j.bbmt.2013.10.018, indexed in Pubmed: 24161923.

11. Rondelli D, Goldberg JD, Isola L, et al. MPD-RC 101 prospective study of reduced-intensity allogeneic hematopoietic stem cell transplantation in patients with myelofibrosis. Blood. 2014; 124(7): 1183-1191, doi: 10.1182/blood-2014-04-572545, indexed in Pubmed: 24963042.

12. Kröger N, Giorgino T, Scott BL, et al. Impact of allogeneic stem cell transplantation on survival of patients less than 65 years of age with primary myelofibrosis. Blood. 2015; 125(21): 3347-50; quiz 3364, doi: 10.1182/blood-2014-10-608315, indexed in Pubmed: 25784679 .

13. James C, Ugo V, Le Couedic JP. A unique clonal JAK2 mutation leading to constitutive signalling causes polycythaemia vera. Nature. 2005; 434(7037): 1144-1148, doi: 10.1038/nature03546, indexed in Pubmed: 15793561.

14. Scott LM, Tong W, Levine RL, et al. JAK2 exon 12 mutations in polycythemia vera and idiopathic erythrocytosis. N Engl J Med. 2007; 356(5): 459-468, doi: 10.1056/NEJMoa065202, indexed in Pubmed: 17267906.

15. Nangalia J, Massie CE, Baxter EJ, et al. Somatic CALR mutations in myeloproliferative neoplasms with nonmutated JAK2. N Engl J Med. 2013; 369(25): 2391-2405, doi: 10.1056/NEJMoa1312542, indexed in Pubmed: 24325359.

16. Klampfl T, Gisslinger H, Harutyunyan AS, et al. Somatic mutations of calreticulin in myeloproliferative neoplasms. N Engl J Med. 2013; 369(25): 2379-2390, doi: 10.1056/NEJMoa1311347, indexed in Pubmed: 24325356.

17. Harrison CN, Vannucchi AM. Closing the gap: genetic landscape of MPN. Blood. 2016; 127(3): 276-278, doi: 10.1182/ /blood-2015-10-674101, indexed in Pubmed: 26796107.

18. Andrikovics H, Krahling T, Balassa K, et al. Distinct clinical characteristics of myeloproliferative neoplasms with calreticulin mutations. Haematologica. 2014; 99(7): 1184-1190, doi: 10.3324/ /haematol.2014.107482, indexed in Pubmed: 24895336.

19. Tefferi A, Guglielmelli P, Lasho TL, et al. CALR and ASXL1 mutations-based molecular prognostication in primary myelofibrosis: 
an international study of 570 patients. Leukemia. 2014; 28(7): 1494-1500, doi: 10.1038/leu.2014.57, indexed in Pubmed: 24496303.

20. Vannucchi AM, Lasho TL, Guglielmelli P. Mutations and prognosis in primary myelofibrosis. Leukemia. 2013; 27(9): 1861-1869, doi: 10.1038/leu.2013.119., indexed in Pubmed: 23619563.

21. Guglielmelli P, Lasho TL, Rotunno G, et al. The number of prognostically detrimental mutations and prognosis in primary myelofibrosis: an international study of 797 patients. Leukemia. 2014; 28(9): 1804-1810, doi: 10.1038/leu.2014.76, indexed in Pubmed: 24549259 .

22. Tefferi A, Wassie EA, Lasho TL, et al. CALR vs JAK2 vs MPL-mutated or triple-negative myelofibrosis: clinical, cytogenetic and molecular comparisons. Leukemia. 2014; 28(7): 1472-1477, doi: 10.1038/leu.2014.3, indexed in Pubmed: 24402162.

23. Tefferi A, Pardanani A, Gangat N, et al. Leukemia risk models in primary myelofibrosis: an International Working Group study. Leukemia. 2012; 26(6): 1439-1441, doi: 10.1038/leu.2011.374, indexed in Pubmed: 22289985.

24. Gangat N, Caramazza D, Vaidya R, et al. DIPSS plus: a refined Dynamic International Prognostic Scoring System for primary myelofibrosis that incorporates prognostic information from karyotype, platelet count, and transfusion status. J Clin Oncol. 2011; 29(4): 392-397, doi: 10.1200/JCO.2010.32.2446, indexed in Pubmed: 21149668.

25. Caramazza D, Begna KH, Gangat N, et al. Refined cytogenetic-risk categorization for overall and leukemia-free survival in primary myelofibrosis: a single center study of 433 patients. Leukemia. 2011; 25(1): 82-88, doi: 10.1038/leu.2010.234, indexed in Pubmed: 20944670.

26. Bacigalupo A, Soraru M, Dominietto A, et al. Allogeneic hemopoietic SCT for patients with primary myelofibrosis: a predictive transplant score based on transfusion requirement, spleen size and donor type. Bone Marrow Transplant. 2010; 45(3): 458-463, doi: 10.1038/bmt.2009.188, indexed in Pubmed: 19718055.

27. Wong KM, Atenafu EG, Kim D, et al. Incidence and risk factors for early hepatotoxicity and its impact on survival in patients with myelofibrosis undergoing allogeneic hematopoietic cell transplantation. Biol Blood Marrow Transplant. 2012; 18(10): 1589-1599, doi: 10.1016/j.bbmt.2012.04.011, indexed in Pubmed: 22531490.

28. Kerbauy DMB, Gooley TA, Sale GE, et al. Hematopoietic cell transplantation as curative therapy for idiopathic myelofibrosis, advanced polycythemia vera, and essential thrombocythemia. Biol Blood Marrow Transplant. 2007; 13(3): 355-365, doi: 10.1016/j. bbmt.2006.11.004, indexed in Pubmed: 17317589.

29. Schmohl JU, Groh C, Faul C, et al. Allogeneic hematopoietic cell transplantation in patients with myelofibrosis: A single center experience. Ann Hematol. 2016; 95(6): 973-983, doi: 10.1007/ /s00277-016-2644-8, indexed in Pubmed: 27021303.

30. Nakaya A, Mori T, Tanaka M, et al. Does the hematopoietic cell transplantation specific comorbidity index (HCT-CI) predict transplantation outcomes? A prospective multicenter validation study of the Kanto Study Group for Cell Therapy. Biol Blood Marrow Transplant. 2014; 20(10): 1553-1559, doi: 10.1016/j. bbmt.2014.06.005, indexed in Pubmed: 25034961.

31. Harrison CN, Vannucchi AM, Kiladjian JJ, et al. Long-term findings from COMFORT-II, a phase 3 study of ruxolitinib vs best available therapy for myelofibrosis. Leukemia. 2016; 30(8): 1701-1707, doi: 10.1038/leu.2016.148, indexed in Pubmed: 27211272.

32. Spoerl S, Mathew NR, Bscheider M, et al. Activity of therapeutic JAK 1/2 blockade in graft-versus-host disease. Blood. 2014;
123(24): 3832-3842, doi: 10.1182/blood-2013-12-543736, indexed in Pubmed: 24711661.

33. Carniti C, Gimondi S, Vendramin A, et al. Pharmacologic inhibition of JAK1/JAK2 signaling reduces experimental murine acute GVHD while preserving GVT effects. Clin Cancer Res. 2015; 21(16): 3740-3749, doi: 10.1158/1078-0432.CCR-14-2758, indexed in Pubmed: 25977345.

34. Kröger N, Kadir S, Zabelina T. Ruxolitinib during peritransplant period for myelofibrosis patient undergoing allogeneic stem cell transplantation reduces acute graft-versus-host disease. Blood. 2016; 128: 2242.

35. Jaekel N, Behre G, Behning A, et al. Allogeneic hematopoietic cell transplantation for myelofibrosis in patients pretreated with the JAK1 and JAK2 inhibitor ruxolitinib. Bone Marrow Transplant. 2014; 49(2): 179-184, doi: 10.1038/bmt.2013.173, indexed in Pubmed: 24292520.

36. Stübig T, Alchalby H, Ditschkowski M, et al. JAK inhibition with ruxolitinib as pretreatment for allogeneic stem cell transplantation in primary or post-ET/PV myelofibrosis. Leukemia. 2014; 28(8): 1736-1738, doi: 10.1038/leu.2014.86, indexed in Pubmed: 24569777.

37. Robin M, Francois, S, Huynh A, et al. Ruxolitinib before allogeneic hematopoietic stem cell transplantation (HSCT) In patients with myelofibrosis: a preliminary descriptive report of the JAK ALLO study, a phase II trial sponsored by Goelams-FIM in collaboration with the Sfgmtc. Blood. 2013; 122: 306.

38. Shanavas M, Popat U, Michaelis LC, et al. Outcomes of Allogeneic Hematopoietic Cell Transplantation in Patients with Myelofibrosis with Prior Exposure to Janus Kinase 1/2 Inhibitors. Biol Blood Marrow Transplant. 2016; 22(3): 432-440, doi: 10.1016/j. bbmt.2015.10.005, indexed in Pubmed: 26493563.

39. Masarova L, Popat UR, Bose, , et al. Allogeneic stem cell transplantation versus medical therapy in patients with advanced myelofibrosis: matched survival analysis and the effect of JAK2 inhibitor therapy. Blood. 2016; 128: abstract 4687.

40. Robin M, Tabrizi R, Mohty M, et al. Allogeneic haematopoietic stem cell transplantation for myelofibrosis: a report of the Société Française de Greffe de Moelle et de Thérapie Cellulaire (SFGM-TC). Br J Haematol. 2011; 152(3): 331-339, doi: 10.1111/j.13652141.2010.08417.x, indexed in Pubmed: 21133885.

41. Kröger N, Holler E, Kobbe G, et al. Allogeneic stem cell transplantation after reduced-intensity conditioning in patients with myelofibrosis: a prospective, multicenter study of the Chronic Leukemia Working Party of the European Group for Blood and Marrow Transplantation. Blood. 2009; 114(26): 5264-5270, doi: 10.1182/ /blood-2009-07-234880, indexed in Pubmed: 19812383.

42. Tefferi A, Barbui T, Tefferi A. Primary myelofibrosis: 2017 update on diagnosis, risk-stratification, and management. Am J Hematol. 2016; 91(12): 1262-1271, doi: 10.1002/ajh.24592, indexed in Pubmed: 27870387.

43. Armand P, Kim HT, Virtanen JM, et al. Iron overload in allogeneic hematopoietic cell transplantation outcome: a meta-analysis. Biol Blood Marrow Transplant. 2014; 20(8): 1248-1251, doi: 10.1016/j. bbmt.2014.04.024, indexed in Pubmed: 24769316.

44. Kataoka K, Nannya Y, Hangaishi A, et al. Influence of pretransplantation serum ferritin on nonrelapse mortality after myeloablative and nonmyeloablative allogeneic hematopoietic stem cell transplantation. Biol Blood Marrow Transplant. 2009; 15(2): 195-204, doi: 10.1016/j.bbmt.2008.11.012, indexed in Pubmed: 19167679.

45. Dadwal SS, Tegtmeier B, Liu X, et al. Impact of pretransplant serum ferritin level on risk of invasive mold infection after allo- 
geneic hematopoietic stem cell transplantation. Eur J Haematol. 2015; 94(3): 235-242, doi: 10.1111/ejh.12421, indexed in Pubmed: 25082161.

46. Kim YuRi, Kim JS, Cheong JW, et al. Transfusion-associated iron overload as an adverse risk factor for transplantation outcome in patients undergoing reduced-intensity stem cell transplantation for myeloid malignancies. Acta Haematol. 2008; 120(3): 182-189, doi: 10.1159/000187646, indexed in Pubmed: 19129689.

47. Trottier BJ, Burns LJ, DeFor TE, et al. Association of iron overload with allogeneic hematopoietic cell transplantation outcomes: a prospective cohort study using R2-MRI-measured liver iron content. Blood. 2013; 122(9): 1678-1684, doi: 10.1182/ /blood-2013-04-499772, indexed in Pubmed: 23777771.

48. Carreau N, Tremblay D, Savona M, et al. Ironing out the details of iron overload in myelofibrosis: Lessons from myelodysplastic syndromes. Blood Rev. 2016; 30(5): 349-356, doi: 10.1016/j. blre.2016.04.003, indexed in Pubmed: 27106071.

49. Murata M, Nishida T, Taniguchi S, et al. Allogeneic transplantation for primary myelofibrosis with BM, peripheral blood or umbilical cord blood: an analysis of the JSHCT. Bone Marrow Transplant. 2014; 49(3): 355-360, doi: 10.1038/bmt.2013.180, indexed in Pubmed: 24270391

50. Bregante S, Dominietto A, Ghiso A, et al. Improved Outcome of Alternative Donor Transplantations in Patients with Myelofibrosis: From Unrelated to Haploidentical Family Donors. Biol Blood Marrow Transplant. 2016; 22(2): 324-329, doi: 10.1016/j. bbmt.2015.09.028, indexed in Pubmed: 26456259.

51. Robin M, Giannotti F, Deconinck E, et al. Eurocord and Chronic Malignancies Working Party-European Group for Blood and Marrow Transplantation (CMWP-EBMT). Unrelated cord blood transplantation for patients with primary or secondary myelofibrosis. Biol Blood Marrow Transplant. 2014; 20(11): 1841-1846, doi: 10.1016/j.bbmt.2014.06.011, indexed in Pubmed: 24946719.

52. Patriarca F, Bacigalupo A, Sperotto A, et al. GITMO. Allogeneic hematopoietic stem cell transplantation in myelofibrosis: the 20year experience of the Gruppo Italiano Trapianto di Midollo Osseo (GITMO). Haematologica. 2008; 93(10): 1514-1522, doi: 10.3324/ /haematol.12828, indexed in Pubmed: 18728030.

53. Ballen KK, Shrestha S, Sobocinski KA, et al. Outcome of transplantation for myelofibrosis. Biol Blood Marrow Transplant. 2010; 16(3): 358-367, doi: 10.1016/j.bbmt.2009.10.025, indexed in Pubmed: 19879949 .

54. Abelsson J, Merup M, Birgegård G, et al. Nordic MPD Study Group. The outcome of allo-HSCT for 92 patients with myelofibrosis in the Nordic countries. Bone Marrow Transplant. 2012; 47(3): 380-386, doi: 10.1038/bmt.2011.91, indexed in Pubmed: 21552298 .

55. Lussana F, Rambaldi A, Finazzi MC, et al. Allogeneic hematopoietic stem cell transplantation in patients with polycythemia vera or essential thrombocythemia transformed to myelofibrosis or acute myeloid leukemia: a report from the MPN Subcommittee of the Chronic Malignancies Working Party of the European Group for Blood and Marrow Transplantation. Haematologica. 2014;
99(5): 916-921, doi: 10.3324/haematol.2013.094284, indexed in Pubmed: 24389309.

56. Gergis U, Kuriakose E, Shore T, et al. Allogeneic Transplantation for Patients With Advanced Myelofibrosis: Splenomegaly and High Serum LDH are Adverse Risk Factors for Successful Engraftment. Clin Lymphoma Myeloma Leuk. 2016; 16(5): 297-303, doi: 10.1016/j.clml.2016.02.004, indexed in Pubmed: 27025789.

57. Markiewicz M, Dzierzak Mietla M, Wieczorkiewicz A, et al. Safety and outcome of allogeneic stem cell transplantation in myelofibrosis. Eur J Haematol. 2016; 96(3): 222-228, doi: 10.1111/ /ejh.12572, indexed in Pubmed: 25899468.

58. Alchalby H, Badbaran A, Zabelina T, et al. Impact of JAK2V617F mutation status, allele burden, and clearance after allogeneic stem cell transplantation for myelofibrosis. Blood. 2010; 116(18): 3572-3581, doi: 10.1182/blood-2009-12-260588, indexed in Pubmed: 20489052.

59. Anasetti C, Logan BR, Lee SJ, et al. Blood and Marrow Transplant Clinical Trials Network. Peripheral-blood stem cells versus bone marrow from unrelated donors. N Engl J Med. 2012; 367(16): 1487-1496, doi: 10.1056/NEJMoa1203517, indexed in Pubmed: 23075175.

60. Stasia A, Ghiso A, Galaverna F, et al. CD34 selected cells for the treatment of poor graft function after allogeneic stem cell transplantation. Biol Blood Marrow Transplant. 2014; 20(9): 1440-1443, doi: 10.1016/j.bbmt.2014.05.016, indexed in Pubmed: 24862637.

61. Klyuchnikov E, El-Cheikh J, Sputtek A, et al. CD34(+)-selected stem cell boost without further conditioning for poor graft function after allogeneic stem cell transplantation in patients with hematological malignancies. Biol Blood Marrow Transplant. 2014; 20(3): 382-386, doi: 10.1016/j.bbmt.2013.11.034, indexed in Pubmed: 24321747.

62. Champlin RE, Horowitz MM, van Bekkum DW, et al. Graft failure following bone marrow transplantation for severe aplastic anemia: risk factors and treatment results. Blood. 1989; 73(2): 606-613, indexed in Pubmed: 2644980.

63. Petersdorf EW, Hansen JA, Martin PJ, et al. Major-histocompatibility-complex class I alleles and antigens in hematopoietic-cell transplantation. N Engl J Med. 2001; 345(25): 1794-1800, doi: 10.1056/NEJMoa011826, indexed in Pubmed: 11752355.

64. Storb R, Prentice RL, Thomas ED, et al. Factors associated with graft rejection after HLA-identical marrow transplantation for aplastic anaemia. Br J Haematol. 1983; 55(4): 573-585, indexed in Pubmed: 6231046.

65. Marmont AM, Horowitz MM, Gale RP. T-cell depletion of HLA-identical transplants in leukemia. Blood. 1991; 78(8): 2120-2130, indexed in Pubmed: 1912589.

66. Arranz L, Sánchez-Aguilera A, Martín-Pérez D, et al. Neuropathy of haematopoietic stem cell niche is essential for myeloproliferative neoplasms. Nature. 2014; 512(7512): 78-81, doi: 10.1038/ /nature13383, indexed in Pubmed: 25043017.

67. Alchalby $\mathrm{H}$, Yunus DR, Zabelina T, et al. Incidence and risk factors of poor graft function after allogeneic stem cell transplantation for myelofibrosis. Bone Marrow Transplant. 2016; 51(9): 1223-1227, doi: 10.1038/bmt.2016.98, indexed in Pubmed: 27088376. 